\title{
The Faces of Conflict in a Political Organization: The case of the Indonesia Democracy Party of Struggle (Partai Demokrsi Indonesia Perjuangan PDI-P)
}

GatutPriyowidodo

Grace Swestin

Titi NurVidyarini

Department of Communication Studies,

Petra Christian University,

JalanSiwalankerto 121-131 Surabaya, Indonesia

(gatpri@petra.ac.id, grace.swestin@gmail.com, vidya@petra.ac.id)

\section{DOI:10.5901/mjss.2014.v5n19p608}

\begin{abstract}
The conduct of a political party as an organization is suffused with culture with its own values, concepts and meanings. Indonesia is an interesting case in point. In this paper, the writers expound on the dynamics of organizational conflicts experienced by the Indonesia Democracy Party of Struggle (Partai Demokrasi Indonesia Periuangan/PDI-P) as an opposition party in Indonesia for two decades. By utilizing a phenomenographic approach to capture the participation, perception and understanding of party leaders and members, this paper focuses on three research problems, namely the levels of internal party conflicts, styles of conflict management and factors that influences the process of conflict resolution. There are several highlighted findings. First, the level of conflict occurs on the levels of inter-organizational, intergroup, intragroup, and interpersonal. Secondly, the styles of conflict management adopted by individuals in the party consist of collaborative, competitive, accommodating, compromising and avoidance styles, which vary according to character, political needs, and ideology. Lastly, conflict resolution in the party is heavily influenced by (1) personal factors such as individual member's conceptions on internal party conflicts as well as their references to how conflicts have been solved before; (2) relational factors, i.e. relationships between members of the party which are fostered by an interdependence to reach a common goal as an opposition party, and (3) PDI-P's organizational culture which is built around a juxtaposition between the heterogeneity of geographical and ideological backgrounds and the authority of a charismatic leadership.
\end{abstract}

Keywords: political organization, conflict resolution, phenomenographic approach

\section{Introduction}

PDI-P and conflicts are like two sides of a coin. This fact reinforces the historical roots of the policy to merge five political parties (PNI, IPKI, Parkindo, Catholic and Murba Party) who later delivered PDI (then changed to PDI-P) were still problematic. In 2006-2007, internal conflict occurs. At that time, the party is experiencing crisis in which many members, such as Roy BB Janis (Chairman of the PDI-P Jakarta DPD), Laksamana Sukardi (DPP Treasurer), Dimmy Hartono, HaryantoTaslam, Permadi and others were leaving the party. In fact, when PDI-P won the Legislative General Election on April 2014, thus entitled to nominate Joko Widodo as the candidate for the President of the Republic of Indonesia (20142019), a conflict arises.

At the regional level, a conflict ensued in several Regional Leadership Councils (Provincial Level), particularly during gubernatorial election. East Java Governor elections in 2006, both camps Soetjipto and Soekarwo claim to be the most supported by the people. The facts were clear, as a political organization PDI-P is saving potential conflict energy. Even if it is not managed properly, that energy will continue to explode into conflict manifest, which not easily resolved.

Based on the variation of the above phenomenon, this study formulates several research question, What are the levels of conflict that occur in PDI-P and what are the conflict management strategies that are employed by the party in the case of the East Javanese gubernatorial election of 2009-2013? The purpose of this research is to gain an overview of the level of 
conflict and conflict settings and patterns of conflict resolution as a solution to the internal conflict in the organization of political parties in East Java, Indonesia.

\section{Literature Review}

\section{Conflict in Organizational Communication}

Organizational communication is a key factor in maintaining organizational climate (Drenth et al, 1998). In an organization, conflict is common. Numerous studies have proven that it is both necessary and useful as a part of organizational life. Rahim (2002) conceptualizes conflict as an interactive process manifested in incompatibility, disagreement, or dissonance within or between social entities. Interestingly, Putnam and Poole (1987) views conflict not only from the perspective of mismatches that happened between individuals in organization, but also as deriving from the fact that these individuals are dependent on each other. As such, according to them, conflict is "the interaction of interdependent people who perceive opposition of goals, aims, and values and who see the other party as potentially interfering with the realization of these goals" (p. 552).

Based on who is involved in an organizational conflict, there are four types of organizational conflict, as follows:

1. Interpersonal conflict is the conflict that happens between two individuals. The sources of this conflict may be personal dislikes or personality differences (Jones \& George, 2008)

2. Intragroup conflict is the conflict that occurs inside a group, team or department. This type of conflict involves more than one person within a group ((Jones \& George, 2008)

3. Intergroup conflict is the conflict that happens between different groups, teams or departments that involves aggregates of people within an organization (Miller, 2009)

4. Interorganizational conflict is the conflict between different organizations (Jones \& George, 2008). There are three types of interorganizational conflict: substantive conflict-a conflict which arises in a fundamental level, emotional conflict-a conflict that happens when people from different organizations disagrees due to a reaction on an emotional level, and cultural conflict-a conflict which often occurs due to cultural misunderstanding and stereotyping.

5.

\section{Conflict Management Strategies}

In this context, conflict management refers to conflict resolution and less towards eliminating or reducing conflict. Strategies for conflict management vary according to the "different philosophical bases of those involved" (Treslan, 1993). Thomas (1976) divides styles of conflict management into five types. His typology can be used to identify conflicts and behaviors of individuals commonly associated with each type. The five types of organization member based on their style of conflict management (Hall, 1969; Blake and Mouton, 1960; Kliman and Thomas, 1975 in Pace and Faules, 1994, p. 251) are:

1. Competitor or tough battler. The person who employs this style pursues his or her own concerns somewhat ruthlessly and generally at the expense of other members of the group.

2. Collaborator or problem solver. The person who employs this style seek to create a situation in which the goal of all parties involved can be accomplished. The problem solver works at finding mutually acceptable solutions.

3. Compromiser or manoeuvring conciliator. The person who employs this style assumes that everyone involved in a disagreement stands to lose, and he or she works to help find a workable position.

4. Accommodator or friendly helper. The person who employs this style is somewhat non assertive and quite cooperative, neglecting his or her own concerns in favor of those of others. When a decision is reached, the accommodator may go along and wish later that he or she had expressed some reservations.

5. Avoider or impersonal complier. The person who employs this style tends to view conflict as unproductive and somewhat punishing. The result is usually an impersonal reaction to the decision and little commitment to future action.

The process of conflict management can be differentiated into three types according to Miller (2009): 
1.Personal factors, which include personality, gender (Putnam and Poole, 1987; Wood and Bell, 2008), and the way an individual frames or perceives a conflict (Dewulf, et al., 2009; Lewicky, Gray and Elliot, 2003)

2.Relational factors, which takes into account the relationship between conflicting parties. Putnam and Poole (1987), for instance, noted that hierarchical level affects the way individuals deal with conflict. Another relational aspect is the influence that relationship has on the interaction through which conflict management takes place. Jameson (2004) discovered that the contradiction between maintaining independence and the need for interdependence among workers can affect the way conflict is dealth with.

3.Cultural factors, which includes organizational culture, national culture, and ethnic culture. Brett and Okumura (1998) studied intercultural negotiations among Japanese and U.S. negotiators and discovered that they work under different conflict schemes. Ethnic and racial culture affects the way individuals approach conflict, as Turner and Shuter (2004) discovered in in how African American and European American women approach workplace conflict. Finally, organizational culture plays a crucial role in the process of conflict resolution. Geist (1995) examined how culture built around power relationships, technology and the interest of organizational groups affects perceptions on conflict and its resolution.

\section{Research Method}

In order to achieve the objectives of the study, a qualitative approach, specifically, a phenomenographic approach was adopted. Phenomenography implements an empirical approach in which the researchers investigate the experiences of others (Marton and Booth, 1997). Miller (2007) purports that phenomenography approaches participation, perception and understanding, as well as conception. By adopting phenomenography, the researchers seek to describe, analyse, and understand the experiences of organizational members that were or had been involved in party conflicts.

As such, the core aspect of this research is the data that is primarily collected through in-depth interviews with members of the PDI-P party, who are selected by means of purposive sampling. The informants in this study consist of party members from the top management and middle management positions, as well as party members. The analysis is based on the informants' experiences and perceptions on organizational conflicts in the party. Expositions uttered by individuals in the political party were studied to discover the levels of conflict, styles of conflict management and aspects that influences conflict management.

\section{Findings of Research}

\section{The levels of Conflict}

This research takes place atPDI-P East Java Local Council, with a focus towards the East Java governor election period of 2008-2013. At least four levels of conflict were detected. They were inter-organizational, intergroup, intragroup, and interpersonal level. The details are elaborated from the experience of each informant.

\section{Inter-organizational level}

Level of conflict arises, because of the friction that occurs between organizations. PDI-P as the second dominant force (24 seats, 2004 election result) in East Java Legislative Council, the Governor has the right to nominate their own candidate. However, to gain widespread support voice, PDI-P candidate must be paired with another figure that is popular Ridwan Hisham, East Java Golkar figures. On one hand this is considered as an advantage, but on the other hand, the presence of Ridwan may not be able to boost number of votes. Why? Since both Soetjipto as candidates for Governor and Ridwan Hisham as a candidate for lieutenant governor has a support base that is nearly equal to that of the nationalists. By contrast, when a character is juxtaposed with Soetjipto of the Nahdlatul Ulama (NU) will increase the possibility of votes. However, this condition does not occur because the PKB (National Awakening Party) which is a representation NU communityalready have their own candidate.

Another unsupportive fact is Ridwan Hisham is not a representation of the Golkar Party. Because at that time, Golkar also brought its own candidate,Soenarjo paired with Ali Maschan Moesa. For the Golkar party, though in a personal capacity, Ridwan Hisham presence still harms Golkar as an organization. This is evident, because the numbers of candidates from Golkar voters are only fourth at $19.34 \%$. Inter-organizational conflict ensued. This reality confirms that the conflict can be triggered from the decisions made from within the organization. Further explained by Pramono Anung: 
"Conflict is inevitable in the party. It must be solved according to the system and the rules. At the party there are three sources of conflict during the structural formation of the party when the party congress, provincial party convention, and branch convention,the heat arises in the party. The second conflict transpiresduring governor election. And the third is the ethical conflict in legislative elections, the president and so on "(Interview, August 13, 2010).

\section{Intergroup and Intra-group level}

At the national level, during the exodus movement in which Dimmy Haryanto establish a PITA, Laksamana Sukardi and Roy BB Janis founded the PDP (Party of Democratic Renewal), and Permadi and HaryanthoTaslam join Gerindra (Great Indonesia Movement), mirrored the intergroup and intra-group conflict inside PDI-P. Two groups of the pro-change and pro-status quo, fight each other. The pro PDI expect changes back to the spirit of the early struggles. They were convinced that joining other party or establishing new political organization is much better in expressing their principles than staying at PDI Perjuangan.

In the context of the PDI-P East Java, although the conflict remain dormant, tensions were felt. When Sutjipto recommended a candidate for Governor of East Java, the support can not be optimally implemented. Most board supports Sutjipto, but officially support was also given to Soekarwo. On the grass root level, many PDI members supports Soekarwo, due to the consideration of a clear and unequivocal pro-Marhaenism ideology. Supiono admitted, "It is obvious to us to push the grass roots to support Soetjipto, but people may have another thought. In the heart of the people, PDI Perjuangan relates to Karwo. We held a puppet performance inviting pak Mantep. People were coming, but deep down I know their hearts go to Pak Karwo. Beforehand, Pak Karwo's name was entered, before the recommendation to Pak Tjip, which cause Pak Karwo fled to Democratic Party. So, Pak Karwo's good intention to enter PDI needs to be appreciated. "(Interview, August 30, 2010).

Another fact is evident in the grouping of support at the Regional Executive Council. The group led by Ali Mudji gave an all out support to Sutjipto, but other groups were even more inclined to Soekarwo. The existence of polarization in the internal organization of PDI admitted by Ali Mudji:

"It is true there are two camps inside our party. Since the beginning, there has been an inclination to pro-Tjip and proKarwo. Both of them have the right foundation. As they say in the interests of the party cadres how to bring the party, it was not wrong. I think, all this time the work result from the head of the province, who are not coming from the party's cadres, were not great. From hundreds of head of provinces, the great ones are coming from the party cadres. That is one of the considerations". (Interview, 1 April 2010).

The implications of minimum support certainly lead to small number of the votes in the election of the Governor of East Java on July 23, 2008. At the first round of election, candidates were brought from East Java PDI satonly in third place with $21 \%$ of the vote under Soekarwo (26\%) and Khofifah Indar Parawansa (24\%).

Especially for couples Soetjipto-RidwanHisham on successfully winning the first round or win in six districts / cities which is known as the PDI base Trenggalek, Tulungagung, Blitar, Kediri, Malang and Surabaya. Similarly, Kaji and Salam, both also excelled in the six districts of the city. Just the Achsan candidate pair who won in one district Mojokerto. While Soekarwo-Saifullah Yusuf win in 18 districts / cities in East Java.

Taking into account the number of votes which is only $21.18 \%$ SR. This means the same as the number of votes in the 2004 elections, in which PDI in East Java reached 21\%. However, if compared to the 1999 general election (33.8\%), the number fell $12.8 \%$. The numbers acquired relying on the mass of the PDI-P and almost no additional votes from supporters of Ridwan Hisham who is the former Chairman of the Council of the Golkar Party. Such results confirmed that the SR couple cannot get into the second round. That's why in the second stage of the selection PDI must choose one of the two options,Kaji or Karsa. So the choice is given to Kaji. But at the end of the calculation the vote difference are only 60,223 votes, or $0.39 \%$.

\section{Interpersonal level}

So far the party mechanism has been able to accommodate any potential conflict of interest.Later, it was found that the party's internal disputes led to the formation of an alternative board, at the branch level. Even in more detail, the conflict was a reflection of a personal conflict between the incumbent party officials versus the new chairman. Thisconflict occurred at the Branch Executive Council (DPC) Nganjuk PDI. As a result of dissatisfaction with the results of the 2008 Branch 
Conference, DPC Nganjuk has two leaders, Taufiqqurahman's DPC and Susilo Muslims's DPC (2005-2008), which then forces the DPD PDI-P East Java to put one his 'people' Suhandoyo to lead (2008-2010). As described by Supriono experience:

"Well we resolve conflicts usually we use the principle of consensus agreement. If there is no agreement in the deliberations, the rules are enforced. All the rules are clear. Muslims's committee versus pakSuto and me (H Supriono) as secretary.If you want to replace monggo. We leave it to the DPP alone. I brought my SK, DPP recognizes that in panjenengan nggih monggo. It does not matter, the cost is on me. It was official, pakSuto as the chairman and me as secretary. We finished it in good terms. We go to the DPP. But Pak Muslims refused."(Interview, August 30, 2010).

Even in the field, the DPC leadership dualism conflict triggered the seizure of the secretariat office. Because Muslim Susilo will not budge,Taufiqqurahman occupy other office. The increasing support for Taufiqqurahman put Susilo Muslims on marginalized position. Another fact also occurs when there is a member of PAC (Tributary Board) Prambon (Nganjuk) become a legislative candidate from a non PDI-P party, he was sacked from the party. This means that in dealing with internal party conflict, organizational mechanism should be enforced.

The interpersonal conflict implicate minimum vote gained in governor election 2008. It also gives an answer to why an increasing number of votes for S-R pair is insignificant compared to the vote in the legislative elections.

\section{The Styles of Conflict Management}

\section{Collaborative}

Politics is not a black and white issue, but the result of mutual agreement to reach the final destination. That is why the collaboration of different strengths in both internal and external of the organization, needs to be conducted properly. Since the beginning of the nomination Sutjipto and Soekarwo have each claimed their respective supporter bases. In Rakerdasus(Working Meeting of the Special) in Surabaya on February 24, 2007, support to Soekarwo, 22 DPC supported Soekarwo and 11 DPC for Soetjipto, with DPC 5 abstentions. Both have an equal opportunity to obtain a letter of recommendation from the DPP. That is why the Council of East Java proposes both names. When Soetjipto's name approved by the DPP, organizationally all members must secure the letter of recommendation. DPP, according to the Secretary General of PDI P (2005-2010) certainly has a special consideration if the recommendation letter given to Sutjipto. Furthermore, he said:

"The province of East Java is different from other areas. Especially for Mr. Tjipto these are people who never became Secretary General of the Party, the Party Chairman of the Council, vice chairman of the Assembly, so that the party felt the need to give to the relevant privilege."(Interview, August 13, 2010).

The assertion of the DPP is also reinforced by the performance evaluation conducted by the Regional Head of the party cadres from internal and external parties. Militancy and severity of internal party cadres remain much larger than those from outside the cadre. As acknowledged by Ali Mudji:

"I think, all this time the work result from the head of the province, which are not coming from the party's cadres, were not great. From hundreds of head of provinces, the great ones are coming from the party cadres. That is one of the considerations". (Interview, 1 April 2010).

That consideration is a proof that the East Java PDI-P has a strong will in order cadres to lead the second most populous province after West Java. There must be other forces outside PDI-Pto be embraced in order to create a reliable collaborative strength.

\section{Competitive}

Indeed if the aspirations of the grassroots were noted, the defeat can be hindered. At least the pair Sutjipto-Ridwan Hisham who rely on the spirit of mutual cooperation can enter the second round. The pair might defeat Kaji (Khofifah Indar Parawansa-Mudjiono), who is newly formed several weeks before the registration deadline set by the Election Commission of East Java. This anxiety has been voiced by the DPC-DPC upon looking at conditions on the ground but is hampered by the organization system that has set Sutjipto as a candidate for Governor. Although Soetjipto was less popular compared to Soekarwo who won the 2006 convention. Supriono explained: 
"Well ... I cannot understand despite the survey, the recommendation went to pakTjip. To me any candidate is not a problem. But the initial purpose of the party winning the East Java gubernatorial election is missed. For me the decision is following the agency's decision. But I don't know the grassroots' heart, normy wife's heart. I don't know whether she will choose pak Tjip or pak Karwo. Maybe she will vote for pak Karwo. The first step to lose "(Interview, August 30, 2010).

When the candidate from PDI-P lose, one thing needs to be appreciated that as a political organization, PDI-P has given the chance of fair competition for the internal and external candidate. As explained by SWN and Supriono,

"People have different opinion, until somebody looses, the process is fair. There is clarification to lean closer. The defiance is tough, but the process is conducted openly. The party is the place for competition, it has to be managed."

"Let us not see differences as hostility, it is wrong."

Basically, competition is the essence of democracy. It is why, losing in a competition to gain a strategic public position has to be accepted gracefully. The correct democracy principles are the candidate needs the bravery to loose or winning in sportsmanlike.

\section{Accommodating and compromising}

The essence of accommodation and compromise is give and take. Politics must be built on a foundation of mutual understanding. So the individual that is sanctioned by the DPP (Board of Political Party at a national level) must be accepted by members of the party. Although the same opportunities are given to both candidates, apparently based on a consideration of services to the party, the DPP chose Sutjipto. He received the Letters of Recommendation, stating that he is entitled to be PDI-P's candidate for governor of East Java. Sutjipto was then paired with RidwanHisham (as a candidate for Vice-Governor) who would eventually compete with four other governor-vice governor candidate pairs namely KofifahIndarParawansa-Mudjiono, Soenarjo-Ali Maschan Moses, Ahmady-Soehartono and Soekarwo-Saifullah Yusuf. The competition was pretty tight, hence, the candidate of the PDI-P did not manage to enter the second round of the gubernatorial election, because Sutjipto-RidwanHisham only obtained $21 \%$ of the total votes, which placed them in the third position. While the right to advance to the second round belongs to the two pairs with the most votes, namely KofifahIndarParawansa-Mudjiono and Soekarwo-Saifullah Yusuf.

Responding to defeat, the East Javanese chapter of PDI-P assessed that it was because the election was marred by dishonest practices. Initially, KhofifahIndarParawansa-Mudjiono had been declared victorious in two quick counts conducted by the Indonesian Survey Institute and the Indonesian Survey Circle. However, the fact remained that SoekarwoSaifullah Yusuf were declared as the winner of the gubernatorial election. As a result the disgruntled pair filed a judicial review to the Constitutional Court for justice.

Ali Mudji explains this condition:

I believe, if it (the election) was done fairly, of course, Pak De (Soekarwo) could not have won. Yesterday's [election] was not fair as what happened in in Madura. However, in the internal party, there was no problem. This is, once again, a part of a democratic process as I said earlier. In the local election process there needs to be a process of internalization by the party the results of the survey agency" (Interview, 1 April 2010).

Pengalaman lapangan tersebut semakin menguatkan indikasi bahwa upaya konsolidasi diinternal partai memang masih bermasalah. Tarik ulur kepentingan cukup kuat sehingga muncul penilaian bahwa kekalahan bukanlah bentuk ketidaksolidan pengelolaan organisasi tetapi cermin permainan kotor pihak lain yang tidak mampu dikontrol oleh penyelenggara pemilu yakni Komisi Pemilihan Umum Daerah (KPUD). Lebih jauh dijelaskan oleh SW Nugroho, Sekretaris Bidang Internal DPD PDI Perjuangan Jawa Timur demikian:

Such experience reinforced an indication that the consolidation efforts in the political organization are still problematic. The conflicts of interest are so prominent. Party elites and members attempted to show that defeat is not the result of poor organizational management. Instead it indicated foul play who the Regional Election Commission (Election Commission) could not control. SW Nugroho, Secretary of Internal Affairs DPD PDI-P East Java explains:

If we lose, then we have to lose with dignity. If we have a candidate, then god willing we join the race. We are aware that we do not have the money, our opponents have much money, we've got a little money. But the result you can see, first round, PakKarwo [obtained] 26\%, Bu Khofifah 24\% and PakTjip 21\%. We had a little financial capital. We only have mutual cooperation. It was incredible. 
Then in the second round, we joined BuKofifah. I want to say it is because of PDI-P that a solid vote count was gained. Even when we joined Kaji, PDI-P contributed significantly to the number of votes. PDI-P votes were influential. It was also admitted by BuKhofifah (Interview, 1 April 2010).

Due to the fact S-R lost, PDI-P should undertake a political act to balance the competition. So the choice is a compromise action. SWN illustrates this:

So yes, like people bargaining when they're trading, the buyer raises the price bit-by-bit, the seller must also lower the price a little. If both of them do not compromise then there will be no deal. Similarly, compromise is necessary in the political process. Time will tell if a person in the party is able to survive and affect change in the political processes (Interview, 5 April 2010).

\section{Avoidance styles.}

Avoidance is not identical to giving up. However, avoidance strategy can be an effort to minimize political risks as low as possible. Political competitions do not always lead to a win-lose end. But as it often happens, both wins. This fact should be carefully taken into account. The mismatch between organizational decisions and facts in the masses that has unconsciously sow the seeds of discontent amongst the grassroots. As a result, the grassroot opted to elect Soekarwo, the candidate of the Democratic Party (PartaiDemokrat). The only problem is, elite or party leadership refused to pay attention to this fact as if it is just a misconception that was circulated by the media. Party leaders do not believe that Soekarwo actually gained a great number of support from 22 DPC (DewanPimpinanCabang - Party leadership on a local level) based solely on the consideration that DPC that supported him do not have many seats in the parliament. It's different with Sutjipto. Although only supported by 11 DPC, they have a considerable number of seats in the parliament (more than five). SW Nugroho confirmed:

There is a tendency... the districts that support Pak Tjip, although only 11 areas are areas with a large number of PDI-P supporters. So the number of seats filled by PDI-P members is also high. In areas where there is little number of seats, support is low. In Madura, for instance, there is only one seat or two seats, in Bondowoso, four seats... unlike in Malang, Surabaya. More people choose Pak Tjip, although from remote regions. There are also indications of money politics. When it comes to track record, Pak Tjip has suffered a great deal (Interview, April 1, 2010).

A further implication is polarized positions in the party between the pro Sutjipto supporters versus contra Sutjipto, who managed to garner support for the sake of personal interests. This is a form of latent conflict that then instigated efforts to put down Sutjpto. The party branches in the local area (DPP and DPC), would formally support the choice of the central party leadership (DPP). However, there is no emotional attachment directed towards the party leadership's choice.

Manifestations of latent conflict are taking shape in a variety of forms. This includes the lack of support of DPC, which during the convention supported Soekarwo. Impact can also be felt at the level of DPD East Java. This latent conflict did not become a manifest conflict. However, when a party is not solid in managing the behaviour of its members, then this is a form of failure to run the party's internal organization. The result PDI-P twice failed to deliver its cadres to sit in the executive branch of the province of East Java, especially in the gubernatorial elections in 2003 and 2008.

However, PDI-P was also well aware that defeat is not the end of everything. If the governor's race in 2008 was lost, and the governor's race in 2013 they also lost, there must be a mechanism of nomination that must be fixed.

\section{Factors that Affect Conflict Resolution}

\section{Personal Factors and Relational factors}

The central figure is not only an iconic symbol of the party, but must have a unifying force. After three PDI-P Congress $(2000,2005,2010)$, the party still had not moved from the dominance of a central power. Even the Third Congress (2010) which took place in Sanur-Bali, Megawati became the one single person who determines the members of PDI-P eligible to ran for office. In other words, she has full authority to determine the members of the DPP candidates from the party, even the 2014-2019 Presidential candidate of Indonesia from PDI-P. Pramono Anung, Vice Chairman of the House of Representatives who is also the Secretary General of the Democratic Party of Struggle (2005-2010) asserts: 
In the democratic era, the dominant leader slowly began to decrease. Bu Mega was very dominant in 1999 and also Pak SBY in 2009 (Interview in Bandung, August 13, 2010).

In spite of such opinion, the PDI-P, after 41 years-originally called PDI or Partai Demokrasi Indonesia (Indonesian Democratic Party) - or 21 years (since PDI turned into PDI-P or the Indonesian Democratic Party of Struggle, in 1993) has experienced placing the the central figure in different lights. If the pre-1993 period, party figures used to appear and disappear but after that year, the PDI-P only know the name of one figure who is considered capable to carry on the party's leadership, that is Megawati Sukarnoputri. But in the interests of the organization ahead, the reliance on a central figure should be reduced. As recognized by Supriono, the chairman of the PDI-P in the local house of representative in Nganjuk district explains:

\begin{abstract}
Well, I think that's Bu Mega is charismatic. Actually, PDI-P should not rely on the children of Bung Karno. The problem is that what if there is no charismatic leader in the future? We have to learn together. Choosing a leader should not depend on the descendants of BungKarno. I am grateful if the person is charismatic, has great skill. But they should not be chosen because of her charismatic figure but because he/she is wise, capable and love his/her followers" (Interview in Nganjuk-East Java, August 30, 2010).
\end{abstract}

Members never give alternative to replace the leader who distributes the communication flow. The masses in the grassroots still see Megawati not just as a leader but rather as a force that has the authority to integrate all members of the party. Consequently, every time before the party Congress is, held the main theme is support for Megawati that can still continue to lead PDI-P for the next period.

\title{
2. PDI-P's organizational culture
}

The organizational culture, which is based on the decision to hand over all decisions to Megawati as a dominant figure. During the Rakerdasus (Special Area Work Meeting) before the the III Congress on 1 April 2010. All participants coming from all over the DPCs in East Java confirmed their agreement to re-elect Megawati. In fact they state that the PDI remains the opposition party under the leadership of Megawati. It was clear that there was a precondition that was deliberately created to pave the way so that there is no alternative candidate against Megawati in the Congress.

Even when Guruh Soekarnoputra attempted to run as Chairman of the PDI-P, the competition was already closed. Not because the participants was not willing, but the mechanisms that have been opened since the nomination several months before being used by the candidates to socialize.

Recognized or not it Megawati is a phenomenal figure in the course of PDI organization. When the government of the New Order regime tried to end her political career, on the contrary, people actually gave tremendous support for her. The number of votes at the General Election PDI in 1999 increased dramatically to reach 33\% at the national level as well as in East Java reached $33.81 \%$ of the vote.

What is the real reason for Megawati's popularity among the people of Indonesia? Wiwin one of the party cadres who have joined since the 1975 could shed some light:

Based on the real experience in the field that I have experienced. I've always idolized BungKarno (President Sukarno). So BungKarno is symbolized as a bull, no matter what the party's name is. Bung Karno was also the idol of my ancestors. So if Bung Karno is gone, yes ..it should be passed on to his offspring (Interview in Nganjuk, August 9, 2010).

Empirical experience like that, of course, indicates derationalization in determining the choice, even the attitude of political compliance within an organization. In PDI-P, the organizational culture dictates that as long as the people or members of the political party organization see that the organization is still 'on track', there is no other choice except obey. Yadi Susanto, a PDI-P member of the District of ProbolinggoMaron said:

Here's our role in the party, following the rules, the rules of the party and how to implement them for the welfare of the people participated. Then we as members just follow what has been decided that (Interview, 1 April 2010).

The point is to illustrate the fact that the opportunities for different or does not agree with the party leadership is very small. People already put the head of the central figure. The pattern of communication is dominated by the leader and members became very weak and difficult to give feedback. 
But it does not mean that all leaders are decisive. As a label, 'democracy' calls for an obligation to listen to the aspirations of the people. PDI-P also realizes that it develops precisely due to the strong support of the masses. In the general elections after the reformation era in 1998, the party remains in the top three as far as legislative election is concerned. They garnered $33 \%$ of the vote (1999), 19\% (2004) and 14.6\% (2009). Attention to the voice of the people is still considered. Wiwin (Deputy Head of Women's Empowerment and Social Welfare DPC PDI-P Nganjuk) explains:

First of all, decision-making is applied from top to bottom. Then from the branches to the PAC. All has been well implemented. The voice of the people are really taken into account. People is the spearhead of the party. They were the first to move, they move from the bottom. Not from above, no. From the bottom, because those who advance the party "(Interview in Nganjuk, August 9, 2010).

Although in some ways, the dominant party leadership dictates organizational culture, but on other occasions the aspirations of 'grassroots' is also heard. Under such condition, the voice of the people is a winner. If they are not managed well, slowly but surely the tendency to shift to another political party would be great. Experience of defeat twice in East Java gubernatorial elections (2008 and 2013) must be awareness with elite PDI-P, to build a new political culture.

\section{Disscussion}

Election of the Governor of East Java (2009-2014) is an interesting lesson for the PDI-P. Under the terms of the organization, for the nomination of governor is derived from the results Rakercabsus (Special Work Meeting) of DPC in East Java. The participants from 665 Tributary Board (PAC) that determines who is entitled to be nominated. But even if someone's already won at the branch level, they are not automatically entitled to be nominated as a candidate for governor. He first must obtain a recommendation from the PDI-P central leadership. Further SW Nugroho (Internal Secretary DPD PDI-P East Java) said:

For elections (local elections) candidates must be recommended promoted PDI-P. There are two things we as a carrier party or the supporting party. When we send a candidate, we could help other parties as a supporter party. Or a candidate is carried by another party, the PDI-P as a supporter. If the number of popular vote is enough, according to the law, to carry our own candidate, then we will do that. There should be at least $15 \%$ of the seats. In particular it as a candidate, must have a recommendation from the DPP. In the selection of regents or mayors in the area that do not get PDIP's 15\% and had to join another party or join as a carrier, there will be no recommendation This means that it is the local DPC who should determine it without recommendation. But for areas that have the vote required, they could get a recommendation (Interview, 1 April 2010).

The issuance of a letter of recommendation is what seems to be the control of the DPP to DPD. Moreover if the DPD proposes two candidates with equal electability. At the election of Governor East Java Province in 2009, there were two candidates nominated for the PDI-P, namely Soekarwo (bureaucrats) and Soetjipto (former Chairman of the Council and the Secretary General of Democratic Party of Struggle). Then the rational considerations are often defeated by the emotional sensitivity based on the 'track record' of each candidate in the party. According to the experience of Pramono Anung, communications and discussions were conducted intensively prior to the DPP's issuance of recommendations. In addition to seeing candidates' popularity based on survey results, they also need to be considered on their merits in the organization. As said by Pramono Anung:

The province of East Java is different from other areas. Especially for Mr.Tjipto these are people who had became Secretary General of the Party, the Party Chairman of the Council, vice chairman of the National Assembly, so that the party felt the need to give to a privilege. We also conducted a survey. Actually, based on the survey results and the differences between Pak Karwo and PakTjipto was not too much. Indeed pack Karwo was superior but the consideration was between cadre and non-cadre. No matter what, Tjipto pack is a cadre, he was the former Secretary General of the party "(Interview, August 13, 2010).

Aligning the interests of the central leadership (DPP) and the region (DPD) is not easy. Of course the pros and cons are very carefully taken into account. At this level, the DPP wants all processes to be carried out according to regulations. The only problem is, when trying to sell a 'political product' in the local elections, it is certainly not merely the concern the internal organization, but the grassroot. The DPP and DPD as the party elite tried hard not to resist the voice of the people 
(grassroots). They accommodated it through rakercabsus (special work meeting) so that aspirations can be communicated directly to members of the party elite.

Of the relational dimension, equality of the relationship is important, but when the elite (DPP and DPD) remains at its choice and ignore the will of the members, the results are expected to not be optimal. Each person has a different experience though variations are exposed to the same phenomena. Especially in an organization that is full of political intrigue and interest respectively. This picture more was clearly expressed by SW Nugroho thus:

When PDI-P chose to recommend pack Tjip, there were rumors. Yet if we look at the people who choose to pack Tjip of the DPC in the number of people choosing PakTjip are numerous there (Interview, April 1, 2010).

What is at stake ultimately depends on the public, whether or not the majority of members or sympathizers of the PDI-P still favor him or not. It should be taken into account exactly in order to avoid ambiguity in assessing the people's voice. So the organization, as a formal forum that bridges the interests of the people and the elite must be professionally managed. In the event of either an internal or external conflict, ingroup or intergroup, personal or inter organizational, the organization according to Shockley-Zalabak (2012) must have instruments that directs how conflicts should be resolved. According to Papa, Daniel and Spicker (2008) should be appropriate to the context in which the organization was located.

\section{Conclusion}

Based on the aforementioned conflict-related level, each informant in PDI-P recognizes they have the levels of conflict. They formulated the conflict in accordance with the scope (the referential aspect). In PDI-P, conflict levels of interpersonal and intergroup occurred in levels. They recognize that when the personal interest is in contrast with the organizational one, then the conflict will eventually emerge. The problem is what brings about the conflict? The implementation process of organizational ideology serves the principle of political struggle of and related to the pragmatic interests of the individual.

The researcher in fact finds that the conflict is rooted from personal interest. Public Officials requires the support of their constituents and economic capacity as well. When one's capability is questioned, this means the public's trust that he / she could run a public office is very limited. Organization should have their future as a consideration. But, if members of the organization think of their current interest then conflicts emerge.

Personal problems may turn into a group issue. If this is not well-managed, inter-organizational problems will certainly emerge. The same thing is also experienced by PDI-P. During the Gubernatorial nomination, the individual members of organization seem to avoid to completely support the organizational decision. They indicated more focus on personal and group's interest. As the result, the support given was not all out.

When the organization makes certain decision, the technical organizer should be the members of the respective organization. They should have strong commitment for the sake of the organization in the future (the structural aspect). If the organization perceives that one does not have the capacity to become a public official (such as Governor), their consideration

But, if the consideration is motivated by ego, then the conflict cannot be prevented. The political conflict is susceptibly penetrated by an external party factor. As the result, the conflict is no longer on the scale of interpersonal, intra-group, nor intergroup, but inter-organization. In politics, such a fact is not avoidable. The reasonable step would be to strengthen the institution and personal capacity of the party's members through training, enforcement of party regulation, and sensitivity to detect the source of conflict and place clear criteria and qualification for the position of Public Officials from within the political party.

\section{Acknowledgement}

The writers are Indebted to DP2M, Directorare of Higher Education, Ministry of Education and Culture through Kopertis 7, East Java, Indonesia for supporting this study through its 2014 Fundamental Research Grant. The writers would also like to thank the Center for Research and Community Service, Petra Christian University, Surabaya, Indonesia. Our gratitude also goes to the informants from the Indonesian Democratic Party of Struggle without whom this research would not have been possible. 


\section{References}

Drenth, P. J .D., Thierry, H., \& De Wolff, C. J., (1998).Handbook of Work and Organizational Psychology (2nd Ed.), East Sussex, PsychologyPress Ltd.

Jones, G.R.,\& George, J.M. (2008). Essentials of Contemporary Management.McGraw Hill Higher Education.

Marton, F. (1981). 'Phenomenography: Describing the conceptions of the world around us'. Instructional Science. 10 (2). 177-200.

Marton, F. (1986). 'Phenomenography — A research approach to investigating different understandings of reality'. Journal of Thought. 21. 28-49.

Marton, F. (1994). 'On the structure of awareness' in John A Bowden \& E. Walsh (eds.), Phenomenographic Research: Variations In Method, The Warburton Symposium, ERADU, RMIT, Melbourne. 89-100.

Marton, F. \& Booth, S. (1997). Learning and Awareness. Mahwah, NJ: Lawrence Erlbaum Associates.

Miller, K. (2009) Organizational Communication : Approaches and Processes. Wadsworth

Miller, T.K. (2007). Prospective elementary teachers's experience in learning mathematics via online discussions: A phenomenographical study. Indiana: Purdue University.

Pace, R.W., \& Faules, D.F. (1994;2006). Komunikasi Organisasi: strategi meningkatkan kinerja perusahaan. Bandung: Remaja Rosdakarya.

Papa, M. J., Daniels, T. D., \& Spicker, B. K. (2008). Organizational communication: Perspectives and trends. London: Sage.

Priyowidodo, G. (2013). Communication Patterns in Decision Making :Phenomenography Approach in Malaysia's and Indonesia's Political Organizations. Doctoral Dissertation. Kedah, Malaysia : School of Multimedia Technology and Communication, University Utara Malaysia.

Putnam, L.L. \& Poole, M.S. (1987). Conflict and Negotiation. In F.M. Jablin, L.L. Putnam, K.H. Roberts \& L.W. Porter (eds.). Handbook of Organizational Communication: An interdisciplinary perspective (pp. 549-599). Newburry Park, CA: Sage

Rahim, A, (2002): Toward theory of managing organizational conflict, The International Journal of Conflict Management, 13 (3). 206-235.

Shockley-Zalabak, P.S. (2012). Fundamental of Organizational Communication, Knowledge, Sensitivity, Skills, Values. Boston: Pearson Allyn\& Bacon

Vagle, M. D. (2009). Validity as intended: 'bursting forth toward' bridling in phenomenological research. International Journal of Qualitative Studies in Education (QSE), 22 (5), 585-605.

Vallee,J. C. (2006). A Phenomenographical approach to understanding students' conceptions of an online learning program. California: Fielding Graduate University.

Viinamaki, O.P., (2009). Intra Organizational Challenges of Values-Based Leadership, EJBO-Electronic Journal of Business Ethics and Organization Studies, 14 (2), 6-13. http://ejbo.jyu.fi/pdf_vol14No2_pages_6-13.pdf 